\title{
Control of Factors Increasing the Preweaning Mortality of Swine in Puerto Rico
}

\author{
A. Gonzâlez-Chapel and Ismael Carlo'
}

\section{THE PROBLEM}

The losses caused by preweaning mortality of swine in the United States amount to several millions dollars a year. There is no way of estimating the monetary value of such losses in Puerto Rico, but it is certain that they are considerable.

According to Smith, (11)2, the losses which occur among young pigs prior to weaning probably constitute the heaviest drain on profits the swine industry is forced to bear. He estimated these losses at about one-third of all the pigs born, including in the mortality pigs born dead. Dale, $(\dot{6})$, stated that it is not unusual for 50 percent or more of the pigs to die during the first few days of life. Bague (3) reported a mortality of 30.41 percent in the herds of the Puerto Rico Reconstruction Administration, although apparently still-born pigs were not included in this estimate.

Many factors are responsible for the preweaning mortality of swine, but the majority of the investigators agree that most of them are under the control of the farmer and thus are preventable.

It was thought that a careful study of the preweaning mortality of the pigs in the Puerto Rico Agricultural Experiment Station herd, with the classification of the causes of death and the analysis of the factors influencing the mortality, might serve as a basis for the preparation of individual programs by the swine producers of the Island to reduce their preweaning losses, and thus adopt a more efficient system of management.

\section{PROCEDURE}

This study covers 9 years, from 1940 to 1949, at the La Plata Animal Production Substation of the Puerto Rico Agricultural Experiment Station.

A total of 158 different sows kept in the herd during the period studied were considered. They included 69 Native, 54 Duroc Jersey, $12 \mathrm{~F}_{1}$ Duroc $\mathrm{x}$ Native, $9 \mathrm{~F}_{1}$ Landrace Large Black $\times$ Native, and $14 \mathrm{~F}_{1}$ Landrace Large Black $x$ Duroc sows.

These sows farrowed 382 litters which included 138 from the Duroc sows,

${ }^{1}$ Associate Animal Husbandman and Assistant Animal Husbandman, respectively, Agricultural Experiment Station, University of Puerto Rico, Río Piedras, P. R. The authors wish to express their appreciation to Dr. J. Rivera Anaya of this Station for his help in evaluating the causes of death of the pigs, and to J. I. Cabrera, also of the Station, for early assistance in the tabulation of data.

${ }^{2}$ Numbers in parentheses refer to Literature Cited p. 223-4. 
184 from the Native sows, and $21 \mathrm{~F}_{2}$ Duroc $\mathrm{x}$ Native, $18 \mathrm{~F}_{2}$ Landrace Large Black $\times$ Native, and $21 \mathrm{~F}_{2}$ Landrace Large Black x Duroc litters. A total of 3,841 pigs were produced in these litters of which 1,750 were from the Duroc sows, 1,487 from the Natives, 228 from the Duroc $x$ Native, 173 Landrace Large Black x Native, and 203 Landrace Large Black x Duroc.

Records were made during the entire period of the number of pigs farrowed, the number weaned, the farrowing weights, and the distribution of mortality. Causes of death were included whenever the information was available.

Throughout the 9 years the same feeding program was followed, based mainly on concentrate feed imported from the United States.

\section{DISTRIBUTION OF MORTALITY}

The 382 litters produced during the period studied by the 158 sows of the different breeds and crossbreeds totaled 3,841 pigs. Of these, 2,469 were weaned, with a mortality, including farrowed dead pigs, of 35.72 percent. The average litter numbered 10.05 pigs of which 6.46 were weaned and 3.59 died before weaning. The distribution of the preweaning mortality is shown in table 1.

Table 1 shows that 70.26 percent of all the pigs that died before weaning were farrowed dead, or died within the first week after farrowing, and that 86.37 percent of all that died were farrowed dead or died within the first month after farrowing. Only 10.06 percent of the deaths occurred in the second month of the weaning period.

Weaver (13) stated that approximately one-half of all preweaning losses occur before the litter is 3 days old, and more than four-fifths by the time the pigs are 2 weeks of age.

TABLE 1.-Distribution in time of the preweaning mortality of $1,37 \mathrm{~F}$ pigs out of 3,841 farrowed

\begin{tabular}{l|c|c|c}
\hline Time of death & Number dead & $\begin{array}{c}\text { Proportion of dead } \\
\text { to total farrowed }\end{array}$ & $\begin{array}{c}\text { Proportion of total } \\
\text { dead }\end{array}$ \\
\cline { 2 - 3 } Still-born & 312 & Percent & Percent \\
1st week & 8.12 & 22.74 \\
2nd week & 119 & 16.97 & 47.52 \\
3d week & 63 & 3.10 & 8.68 \\
4th week & 39 & 1.64 & 4.59 \\
5th-6th weeks & 73 & 1.02 & 2.84 \\
7th-8th weeks & 65 & 1.90 & 5.32 \\
Unknown & 49 & 1.69 & 4.74 \\
Total & 1,372 & 35.72 & 100.00 \\
\hline
\end{tabular}


TABLE 2.-Causes of preweaning mortality among 322 litters of pigs farrowed by Duroc and Native sows

\begin{tabular}{l|c|c}
\hline \multicolumn{1}{c|}{ Cause of death } & Proportion of total farrowed & Proportion of dead \\
\cline { 2 - 3 } & Percent & Percent \\
Weak & 12.82 & 37.32 \\
Born dead & 8.47 & 24.64 \\
Killed by sows & 5.04 & 14.66 \\
Scours & 1.51 & 4.40 \\
Put to other sows & .80 & 2.34 \\
Miscellaneous diseases & .37 & 1.08 \\
Necro & .19 & .54 \\
Abnormal & .12 & .36 \\
Anemia & .09 & .27 \\
Unknown & 4.94 & 14.39 \\
\hline
\end{tabular}

\section{CAUSES OF DEATH}

Causes of death were ascertained for 322 litters farrowed by the Duroc and Native sows, which included 3,237 pigs with a preweaning mortality of 34.35 percent. The causes of death, insofar as they could be determined, are shown in table 2.

Deaths classified as caused by weakness, or of which the cause was unknown, probably included unidentified cases of anemia, starvation, smothering, worms, and pneumonia, although many were of pigs born weak constitutionally.

According to Smith (11) still-born pigs in the United States accounted for 5.2 percent of the total born, and trod-on pigs for 15 percent. In the Station herd more pigs were born dead but fewer were killed by the sows, probably because guard rails were available in the farrowing pens.

Still-birth and congenital weakness accounted for most of the deaths of weanling pigs in this herd. Weaver (13). suggested that pigs may be weak at farrowing time because of nutritional deficiency in the ration of the sow prior to farrowing. Madsen (9) stated that a deficiency of iodine in the ration of pregnant sows leads to the birth of weak offspring. The young pigs may be still-born or they may be born alive and die shortly afterward. However, it is more probable that in this herd the high fertility of the sows was at least a contributing factor for the many still-born and weak pigs produced.

Anemia is probably more prevalent in young pigs in Puerto Rico than is apparent from this study. Hamilton, et al. (8), regarded anemia as an important factor in the mortality of suckling pigs.

Among the classifiable diseases, scours was the main cause of death. 


\section{FACTORS INFLUENGING PREWEANING MORTALITY}

Young pigs are subject to a variety of maladies caused mainly by faulty breeding, nutrition, and management practices. However, some factors indirectly affect the mortality by increasing the propensity of the pigs to fall prey to the different diseases which ultimately cause their death. To a certain extent these factors are also under the control of the farmer. The farrowing season, the breed, the age of the dam, the litter number of the sow the farrowing weight, and the size of the litter are included in the following discussion.

\section{FARROWING SEASON}

The effect of farrowing season on mortality was studied in the 322 litters farrowed by the Duroc and Native sows. Table 3 shows the distribution of the preweaning mortality in the different seasons.

The differences in total mortality were just on the level of statistical significance; there was a strong tendency for the summer litters to have lower preweaning mortality. The differences in mortality during the first week were highly significant; more pigs died during the first week in the spring season. The differences in the number of pigs killed by the sows were also highly significant; in autumn and winter the sows killed more pigs than in spring and summer. Summarizing, mortality was lower in the summer litters because the sorws killed more pigs in autumn and winter, and more pigs died during the first week in the spring.

TABLE 3.-Seasonal distribution of preweaning mortality in 322 litters of pigs farrowed by Duroc and Native sows

\begin{tabular}{|c|c|c|c|c|c|c|c|c|}
\hline \multirow{2}{*}{ Time or cause of death } & \multicolumn{2}{|c|}{ Winter litters } & \multicolumn{2}{|c|}{ Spring litters } & \multicolumn{2}{|c|}{ Summer litters } & \multicolumn{2}{|c|}{ Autumn litters } \\
\hline & Number & Percent & Number & Percent & Number & Percent & Number & Percent \\
\hline Still-born & 65 & 9.12 & 67 & 7.91 & 92 & 8.23 & 50 & 8.94 \\
\hline 1st week & 76 & 10.66 & 137 & 16.17 & 132 & 11.81 & 55 & 9.84 \\
\hline 2nd week & 21 & 2.95 & 24 & 2.83 & 26 & 2.33 & 15 & 2.68 \\
\hline $3 d$ week & 14 & 1.96 & 13 & 1.54 & 11 & .98 & 8 & 1.43 \\
\hline 4th week & 4 & .56 & 6 & .71 & 2 & .18 & 11 & 1.97 \\
\hline 5 th-6th weeks & 8 & 1.12 & 14 & 1.65 & 7 & .63 & 7 & 1.25 \\
\hline 7 th-8th weeks & 7 & .98 & 18 & 2.13 & 10 & .89 & 4 & .72 \\
\hline Unknown & 7 & .98 & 4 & .47 & 29 & 2.59 & 5 & .89 \\
\hline Killed by sows & 41 & 5.75 & 30 & 3.54 & 43 & 3.84 & 49 & 8.77 \\
\hline Total dead & 243 & 34.08 & 313 & 36.95 & 352 & 31.48 & 204 & 36.49 \\
\hline Total farrowed & 713 & & 847 & & 1,118 & & 559 & \\
\hline
\end{tabular}


Hamilton, et al. (8), held that nutritional or milk anemia in suckling pigs is more prevalent in February and March litters than in those farrowed in the late spring, or summer, or fall.

A detailed study of the first-week deaths during the spring indicated, however, that most of them occurred in May, and that at least an important contributing cause was scours. In May 1946, at least 11 pigs with scours died during the first week. According to Dale (6), swine develop enteritis and scours almost entirely because of faulty nutrition and lack of proper housing, care, and sanitation. Although no records of rainfall are available for the period, it is possible that excessive rain made it difficult to keep the pens clean.

McDonald (10) observed that spring weather conditions in the United States are none too favorable for the little pigs. If the pigs are not kept dry and warm, scours may appear.

Bagué (3) concluded that, in La Plata, P. R., preweaning mortality was highest during December, January, and February, because of cold weather. He also suggested a relationship between the dry season and high mortality caused by scarcity of green grass. The dry season coincides with the winter months. This may explain the increased number of pigs killed by the sows during autumn and winter, as reported in this study.

\section{BREED}

Breeds differences in mortality were analyzed in two ways. A comparison was made between the Native and the Duroc sows, regardless of the boars mated to them. The effect of hybrid vigor was studied by comparing the litters produced by Duroc sows mated to Duroc boars and to boars of other breeds, and by the comparison of litters produced by Native sows mated to Native boars and to boars of other breeds.

The distribution in time of the mortality of the 184 litters farrowed by the Native sows and the 138 litters farrowed by the Duroc sows is shown in table 4. The pigs considered included 1,750 from the Native sows and 1,487 from the Duroc sows.

The Duroc sows farrowed litters averaging 11.1 pigs of which 7.1 were weaned and 4 died, or 63.9 percent of the pigs farrowed were weaned. The Native sows farrowed litters averaging 9.62 pigs of which 6.45 were weaned and 3.16 died, or 67 percent of the total pigs farrowed were weaned.

The differences in total mortality between the two breeds were not quite significant. However, there were significant differences in the number of pigs farrowed dead, deaths during the first week, and in the number of pigs killed by the sows. The Duroc sows farrowed more dead pigs and also killed more pigs than the Natives, but the latter lost more pigs during the first week. 
TaBtil 4.-Distribution in time of preweaning mortality of 184 litters farrowed by Native, and 198 litters farrowed by Duroc sows

\begin{tabular}{l|r|r|r|r}
\hline \multirow{2}{*}{ Time or cause of death } & \multicolumn{3}{|c|}{ Duroc } & \multicolumn{2}{c}{ Native } \\
\cline { 2 - 5 } & Number & Percent & Number & Percent \\
\hline Still-born & 154 & 10.36 & 120 & 6.86 \\
1st week & 157 & 10.56 & 243 & 13.89 \\
2nd week & 46 & 3.09 & 40 & 2.29 \\
3d week & 21 & 1.41 & 25 & 1.43 \\
4th week & 15 & 1.01 & 8 & .46 \\
5th-6th weeks & 16 & 1.08 & 20 & 1.14 \\
7th-8th weeks & 17 & 1.14 & 22 & 1.25 \\
Unknown & 9 & .61 & 36 & 2.06 \\
Killed by sows & 101 & 6.79 & 62 & 3.54 \\
\multicolumn{1}{c|}{ Total } & 536 & 36.05 & 576 & 32.91 \\
\hline
\end{tabular}

According to Aubel, et al. (2), there is a very definite relation between the ability of a sow to secrete milk and the number of pigs she is able to raise. It is possible that the Duroc sows could not provide milk for all their pigs because of the large litters. The larger litters might also be expected to cause more farrowed dead pigs among the Durocs. On the other hand, the Native pigs weighed less at farrowing, which would be a possible explanation for the large number of them that died during the first week.

In table 5 is shown the distribution in time and other data related to the mortality of 1,134 purebred Durocs, 136 Duroc $x$ Tamworth, 59 Duroc $x$ Native, and 158 Landrace Large Black $x$ Duroc pigs.

The beneficial effect of hybrid vigor is attested by the fact that the crossbred litters had significantly lower mortality than the purebred Durocs. The heavy mortality of the Durocs was mainly attributable to the many still-born pigs in their litters. The crossbred litters were more vigorous and fewer pigs were farrowed dead.

The Tamworth $\mathrm{x}$ Duroc had lower mortality than the other crossbreds. The Landrace Large Black $x$ Duroc was slightly better than the Duroc $x$ Native. Significantly fewer Landrace Large Black $x$ Duroc pigs were killed by the sows. This may have been because the weight of these pigs was better at birth. Proportionately fewer Tamworth $x$ Duroc pigs died during the first week.

The distribution of the mortality of the Native and Native crossbreds is shown in table 6. Hybrid vigor was not as noticeable in the Native crossbred as in the Duroc crossbred litters. The simultaneous double-cross, Native $x$ Duroe $x$ Hampshire, and the Hampshire $x$ Native had a significantly lower mortality than the Native and the other crossbreds. The 
TABLE 5.-Distribution in time of preweaning mortality of purebred and crossbred Duroc litters

\begin{tabular}{|c|c|c|c|c|c|c|c|c|}
\hline \multirow{2}{*}{$\begin{array}{l}\text { Time of death and other } \\
\text { factors }\end{array}$} & \multicolumn{2}{|c|}{ Duroc } & \multicolumn{2}{|c|}{ Tamworth $\times$ Duroc } & \multicolumn{2}{|c|}{ Duroc $\times$ Native } & \multicolumn{2}{|c|}{$\begin{array}{l}\text { Landrace Large } \\
\text { Black } \times \text { Duroc }\end{array}$} \\
\hline & Number & Percent & Number & Percent & Number & Percent & Number & Percent \\
\hline Still-born & 133 & 11.63 & 7 & 5.15 & 3 & 5.08 & 11 & 6.96 \\
\hline 1st week & 125 & 11.02 & 7 & 5.15 & 7 & 11.86 & 18 & 11.39 \\
\hline 2nd week & 39 & 3.44 & 3 & 2.21 & 1 & 1.69 & 3 & 1.90 \\
\hline $3 d$ week & 14 & 1.23 & 0 & 0 & 3 & 5.08 & 4 & 2.53 \\
\hline 4th week & 15 & 1.32 & 0 & 0 & 0 & 0 & 0 & 0 \\
\hline 5 th-6th weeks & 13 & 1.15 & 0 & 0 & 1 & 1.69 & 2 & 1.27 \\
\hline 7th-8th weeks & 15 & 1.32 & 0 & 0 & 0 & 0 & 2 & 1.27 \\
\hline Unknown & 5 & .44 & 1 & .74 & 0 & 0 & 3 & 1.90 \\
\hline Killed by sows & 86 & 7.58 & 7 & 5.15 & 5 & 8.47 & 3 & 1.90 \\
\hline Total & 445 & 39.24 & 25 & 18.38 & 20 & 33.90 & 46 & 29.11 \\
\hline Litter size & 10.50 & & 12.36 & & 11.80 & & 11.29 & 11.29 \\
\hline Weaned & 6.38 & & 10.09 & & 7.80 & & 8.00 & 8.00 \\
\hline Dead & 4.12 & & 2.27 & & 4.00 & & 3.29 & 3.29 \\
\hline $\begin{array}{l}\text { Proportion weaned of } \\
\text { total farrowed }\end{array}$ & & 60.8 & & 81.6 & & 66.1 & & 70.8 \\
\hline
\end{tabular}

Duroc $x$ Native and the Native litters had a lower mortality than those of the Landrace Large Black $x$ Native and the Tamworth $x$ Native. The heavy mortality in the last two breeds occurred mainly during the first week.

The advantages of crossbreeding on several preweaning and postweaning characteristics of swine were reported for a similar group of pigs in Puerto Rico by A. González Chapel and J. I. Cabrera (7).

\section{AGE OF DAM}

The effect of the age of the dam on the mortality of the litters was studied separately in the Duroc and Native sows. Sows of unknown age were not included in the analysis. Table 7 show the information gathered for each breed.

The differences in total mortality were statistically significant. Pigs from sows that were 16 to 23 months old had the lowest mortality. The greatest mortality was among pigs from sows that were 48 months old or more. The average litter size of the 16 - to 23 -month age group was 8.13 pigs, the smallest among all the age groups. Members of a smaller litter have a better chance of survival and this may have been a contributing factor to the lower mortality shown by the progeny of the 16- to 23-month age group.

The differences in total mortality between the Duroc sows of different 


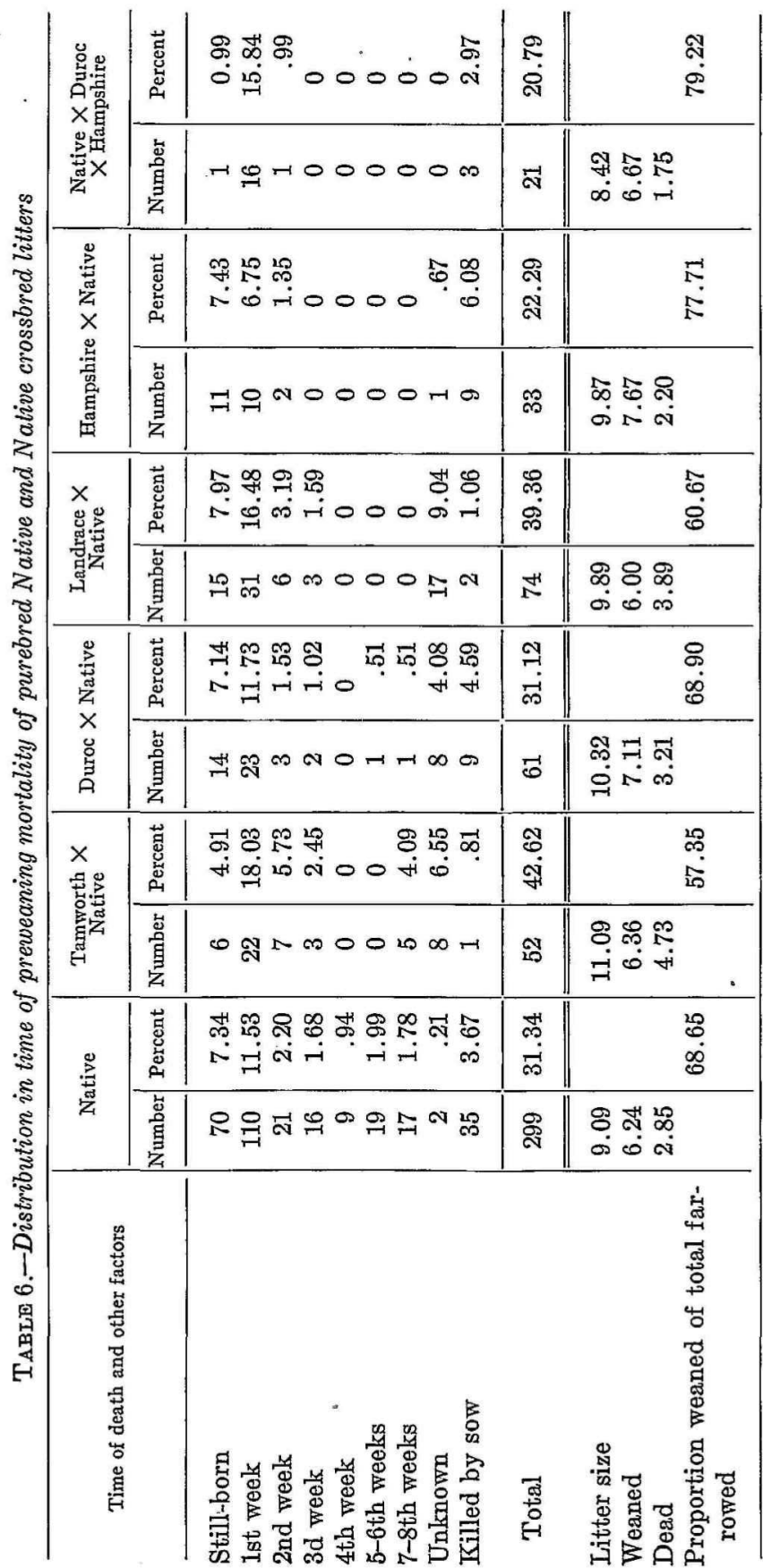


TABLE 7.-Effect of age of dam in months on the distribution in time of preweaning mortality of Native and of Duroc pigs

\begin{tabular}{|c|c|c|c|c|c|c|c|c|c|c|}
\hline \multirow{3}{*}{$\begin{array}{l}\text { Time of death and } \\
\text { other factors }\end{array}$} & \multicolumn{10}{|c|}{ Offspring of sows aged (in months)- } \\
\hline & \multicolumn{2}{|c|}{15 or less } & \multicolumn{2}{|c|}{16 to 23} & \multicolumn{2}{|c|}{24 to 35} & \multicolumn{2}{|c|}{36 to 47} & \multicolumn{2}{|c|}{48 or more } \\
\hline & $\underset{\text { ber }}{\text { Num- }}$ & Percent & $\underset{\text { ber }}{\text { Num- }}$ & Percent & $\left|\begin{array}{c}\text { Num- } \\
\text { ber }\end{array}\right|$ & Percent & $\underset{\text { ber }}{\text { Num- }}$ & Percent & $\begin{array}{c}\text { Num- } \\
\text { ber }\end{array}$ & Percent \\
\hline \multicolumn{11}{|c|}{ Native pigs } \\
\hline Still-born & 10 & 4.61 & 9 & 3.69 & 27 & 5.57 & 24 & 11.88 & 14 & 8.19 \\
\hline 1st week & 23 & 10.60 & 32 & 13.11 & 80 & 16.49 & 26 & 12.87 & 36 & 21.05 \\
\hline 2nd-4th week & 14 & 5.45 & 11 & 4.51 & 19 & 3.92 & 9 & 4.46 & 9 & 5.26 \\
\hline 5th-8th weeks & 16 & 7.37 & 4 & 1.64 & 11 & 2.27 & 3 & 1.49 & 6 & 3.51 \\
\hline Unknown & 6 & 3.77 & 2 & .82 & 17 & 3.51 & 3 & 1.49 & 7 & 4.09 \\
\hline Killed by sows & 5 & 2.30 & 7 & 2.87 & 17 & 3.51 & 6 & 2.97 & 4 & 2.34 \\
\hline Total & 74 & 34.10 & 65 & 26.64 & 171 & 35.26 & 71 & 35.15 & 76 & 44.44 \\
\hline
\end{tabular}

Duroc pigs

\begin{tabular}{|c|c|c|c|c|c|c|c|c|c|c|}
\hline Still-born & 29 & 14.15 & 18 & 6.55 & 28 & 10.39 & 39 & 18.86 & 18 & 14.40 \\
\hline 1st week & 13 & 6.34 & 25 & 9.09 & 44 & 16.18 & 18 & 8.61 & 15 & 12.00 \\
\hline 2nd-4th week & 12 & 5.85 & 12 & 4.36 & 13 & 4.78 & 11 & 5.26 & 4 & 3.20 \\
\hline 5 th-8th weeks & 14 & 6.83 & 7 & 2.55 & 1 & .37 & 1 & .48 & 0 & 0 \\
\hline Unknown & 1 & .48 & 3 & 1.09 & 2 & .73 & 2 & .95 & 1 & .80 \\
\hline Killed by sows & 8 & 3.90 & 10 & 3.64 & 17 & 6.25 & 11 & 5.26 & 9 & 7.20 \\
\hline Total & 77 & 37.56 & 75 & 27.27 & 105 & 38.60 & 82 & 39.23 & 47 & 37.60 \\
\hline Total farrowed & 205 & & 275 & & 272 & & 209 & & 125 & \\
\hline
\end{tabular}

ages were statistically significant. The lowest mortality was also found in the progeny of sows aged 16 to 23 months. The average litter size in this group was again smaller than that of the older groups.

In both the Natives and the Durocs the differences in the mortality between progeny from sows of different ages during the fifth- to the eighthweek period were highly significant. The sows aged 15 months or less lost more pigs during that time than those of other age groups. They also farrowed more dead pigs than the sows 16 to 23 months of age. The heavier mortality of the pigs from sows 24 to 35 months old as compared with that of those from sows 16 to 23 months old occurred mainly because more pigs died during the first week and more pigs were farrowed dead. Sows in the last two age groups farrowed many more dead pigs than sows 16 to 23 months old. 
The differences in pigs killed by sows in different age groups were not significant.

\section{IITTER NUMBER}

The effect of the litter number on preweaning mortality was studied up - to and including the sixth litters of the sows. The data for the Durocs and the Native sows were analyzed separately. Table 8 presents the figures gathered for both the Native and the Duroc sows.

There were 69 Native first litters with an average of 8.14 pigs farrowed and 5.55 weaned; 42 second litters with 9.76 pigs farrowed and 7.17 weaned; 49 third and fourth litters with 10.65 pigs farrowed and 7.08 weaned; and 22 fifth and sixth litters with 10.77 pigs farrowed and 5.95 weaned.

The differences in total mortality between the litters were statistically

TABLE 8.-Effect of litter number on the distribution in time of preweaning mortality of Native and of Duroc pigs

\begin{tabular}{|c|c|c|c|c|c|c|c|c|}
\hline \multirow{3}{*}{$\begin{array}{c}\text { Time of death and } \\
\text { other factors }\end{array}$} & \multicolumn{8}{|c|}{ Results from litter No. } \\
\hline & \multicolumn{2}{|c|}{1} & \multicolumn{2}{|c|}{2} & \multicolumn{2}{|c|}{$3-4$} & \multicolumn{2}{|c|}{$5-6$} \\
\hline & Number & Percent & Number & Percent & Number & Percent & Number & Percent \\
\hline \multicolumn{9}{|c|}{ Native pigs } \\
\hline Still-born & 29 & 5.16 & 16 & 3.90 & 47 & 9.00 & 24 & 10.13 \\
\hline 1st week & 70 & 12.46 & 55 & 13.41 & 67 & 12.84 & 49 & 20.68 \\
\hline $2 n d-4$ th week & 22 & 3.91 & 15 & 3.66 & 18 & 3.45 & 18 & 7.59 \\
\hline 5th-8th week & 22 & 3.91 & 4 & .98 & 11 & 2.11 & 5 & 2.11 \\
\hline Unknown & 13 & 2.31 & 5 & 1.22 & 15 & 2.87 & 3 & 1.27 \\
\hline Killed by sows & 23 & 4.09 & 14 & 3.41 & 17 & 3.26 & 7 & 2.95 \\
\hline Total & 179 & 31.85 & 109 & 26.59 & 175 & 33.52 & 106 & 44.73 \\
\hline Total farrowed & 562 & & 410 & & 522 & & 237 & \\
\hline \multicolumn{9}{|c|}{ Duroc pigs } \\
\hline Still-born & 56 & 10.22 & 23 & 6.46 & 46 & 11.41 & 23 & 15.75 \\
\hline 1st week & 47 & 8.58 & 42 & 11.80 & 47 & 11.66 & 19 & 13.01 \\
\hline 2nd-4th week & 46 & 8.39 & 14 & 3.93 & 15 & 3.72 & 7 & 4.79 \\
\hline 5 th-8th week & 25 & 4.56 & 5 & 1.40 & 3 & .74 & 0 & 0 \\
\hline Unknown & 4 & .73 & 2 & .56 & 2 & .50 & 1 & .68 \\
\hline Killed by sows & 33 & 6.02 & 19 & 5.34 & 34 & 8.44 & 13 & 8.90 \\
\hline Total & 211 & 38.50 & 105 & 29.49 & 147 & 36.48 & 63 & 43.15 \\
\hline Total farrowed & 548 & & 356 & & 403 & & 146 & \\
\hline
\end{tabular}


TABLE 9.-Effect of birth weight on the distribution in time of preweaning mortality of Native and Duroc pigs

\begin{tabular}{l|c|c}
\hline \multirow{2}{*}{ Time of death and other factors } & \multicolumn{2}{|c}{ Birth weight of- } \\
\cline { 2 - 3 } & Natives & Durocs \\
\hline & Pounds & Pounds \\
Still-born & 1.50 & 1.76 \\
1st week & 1.60 & 1.97 \\
2nd week & 1.74. & 2.28 \\
3d week & 2.07 & 2.45 \\
4th week & 1.81 & 2.50 \\
5th-6th weeks & 1.92 & 2.33 \\
7th-8th weeks & 2.01 & 2.42 \\
Unknown & 1.76 & 2.21 \\
Killed by sows & 1.80 & 2.31 \\
\hline
\end{tabular}

significant. The mortality decreased from the first to the second litter and then increased again, reaching a maximum in the fifth and sixth litters. The differences in the number of farrowed dead pigs were also significant. Farrowed dead pigs were more common from the third to the sixth litter.' The differences in the number of deaths during the first week were significant. In the fifth and sixth litters more pigs died during the first week. There were also significant differences in the mortality during the fifth- to eighthweek period. During that period fewer pigs died in the second litters.

The data on the Duroc sows included 55 litters with 9.96 pigs farrowed and 6.13 weaned; 33 second litters with 10.79 pigs farrowed and 7.61 weaned; 35 third and fourth litters with 11.51 pigs farrowed and 7.31 weaned; and 12 fifth and sixth litters with 12.17 pigs farrowed and 6.92 weaned.

The differences in total mortality between the litters were significant. As was the case with the Native pigs, the mortality decreased from the first to the second litters and increased again, with maximum mortality in the fifth and sixth litters. Fewer still-born pigs were found in the second litter and more in the fifth and sixth litters. More pigs died during the fifth-to-eighthweek period in the first litters.

The effect of the litter number on the mortality was similar to the effect of the age of the dam.

\section{FARROWING WEIGHT}

The average birth-weight of the pigs that died before weaning is shown in table 9 for the Native and Duroc sows.

For the Natives the average farrowing weight was 2.04 pounds and the average farrowing weight of the pigs that were weaned was 2.25 pounds. 
The average birth-weight of the pigs that died, regardless of the time of death, was smaller than the average birth-weight of the pigs that were weaned.

For the Durocs the average farrowing weight was 2.44 pounds and the average farrowing weight of the pigs that were weaned was 2.66 pounds. Among the Durocs, as among the Natives, the pigs that died weighed less at birth than the pigs that were weaned. In most cases the birth-weight of the pigs that subsequently died was smaller than the average farrowing weight of the pigs.

Russell, cited by Smith (11), found a relation between the birth-weight and the percentage born dead and the percentage weaned.

The regression of mortality on the farrowing weight is shown in figure 1 both for the Natives and the Durocs. As farrowing weight decreased mortality increased.

\section{SIZE OF LITTER}

The effect of the litter size on preweaning mortality is shown in table 10 for the Native sows. A total of 43 litters composed of 7 pigs or less, 96 litters of 8 to 11 pigs, and 45 litters of 12 or more pigs were included in the analysis.

There were significant differences in mortality. The litters of 12 or more pigs suffered greater mortality than the smaller litters. During the first week fewer pigs died in litters of seven or less.

The information for the Duroc sows is also given in table 10 and includes

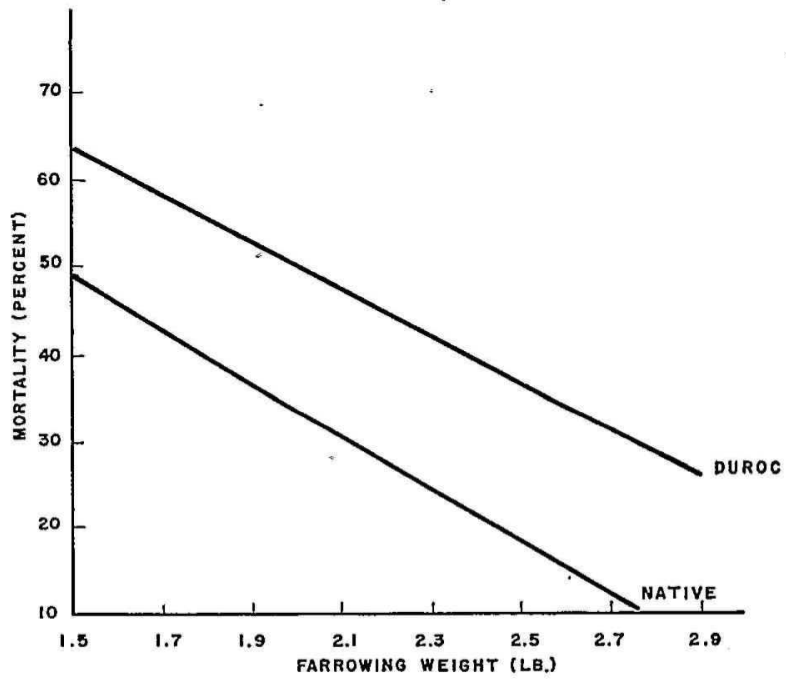

FIG. 1.-Regression of mortality on farrowing weight for Native and Duroc pigs. 
TABLw 10.-Effect of litter size on the distribution in time of preweaning mortality of Native and of Duroc pigs

\begin{tabular}{|c|c|c|c|c|c|c|}
\hline \multirow{3}{*}{$\begin{array}{l}\text { Time of death and } \\
\text { other factors }\end{array}$} & \multicolumn{6}{|c|}{ Results for litters of- } \\
\hline & \multicolumn{2}{|c|}{7 or less } & \multicolumn{2}{|c|}{8 to 11} & \multicolumn{2}{|c|}{12 or more } \\
\hline & Number & Percent & Number & Percent & Number & Percent \\
\hline - & \multicolumn{3}{|c|}{ Native pigs } & \multicolumn{2}{|l|}{$\cdot$} & . \\
\hline Still-born & 18 & 7.89 & 55 & 5.99 & 47 & 7.68 \\
\hline Ist week & 16 & 7.02 & 99 & 10.78 & 128 & 21.19 \\
\hline 2nd-4th weeks & 8 & 3.51 & 31 & 3.38 & 34 & 5.63 \\
\hline 5th-8th weeks & 7 & 3.07 & 24 & 2.61 & 11 & 1.82 \\
\hline Unknown & 5 & 2.19 & 9 & .98 & 22 & 3.64 \\
\hline Krilled by sows & 5 & 2.19 & 41 & 4.47 & 16 & 2.65 \\
\hline Total & 59 & 25.88 & 259 & 28.21 & 258 & 42.72 \\
\hline Total farrowed & 228 & & 918 & & 604 & \\
\hline \multicolumn{7}{|c|}{ Duroc pigs } \\
\hline Still-born & 12 & 12.24 & 46 & 7.85 & 96 & 11.96 \\
\hline 1st week & 6 & 6.12 & 45 & 7.68 & 106 & 13.20 \\
\hline 2nd-4th weeks & 2 & 2.04 & 34 & 5.80 & 46 & 5.73 \\
\hline 5th-8th weeks & 4 & 4.08 & 20 & 3.41 & 9 & 1.12 \\
\hline Unknown & 0 & 0 & $\cdot 4$ & .68 & 5 & .62 \\
\hline Killed by sows & 10 & 10.20 & 33 & 5.63 & 58 & 7.22 \\
\hline Total & 34 & 34.69 & 182 & 31.06 & 320 & 39.85 \\
\hline Total farrowed & 98 & & 586 & & 803 & \\
\hline
\end{tabular}

17 litters of 7 pigs or less, 60 litters of 8 to 11 pigs, and 61 litters of 12 or more pigs.

The differences in mortality were statistically significant. As in the Natives, the litters of 12 or more pigs suffered greater mortality than the smaller litters.

There were significant differences in the mortality from the fifth to the eighth week. In that period lower mortality was observed in litters of 12 pigs or more, than in the other groups; and there was also lower mortality in the litters of 8 to 11 pigs than in those of 7 or less. The same trend, although not significant, was observed in the Natives. Large litters are thus subject to heavier mortality because of more deaths during the first 4 weeks.

González-Chapel and Cabrera (7), with a similar group of pigs, found that individual farrowing weight decreased as size of litter increased. This 
may be the main cause of the heavier mortality of the larger litters. Carmichael, cited by Smith, (11) reported no greater loss in the larger litters, up to 10 , than in the smaller ones. When the number of pigs to the litter exceeded 10 , however, there was a regular tendency, both absolutely and relatively, for the number farrowed dead or immature to increase with the increased size of the litter. Wenck, also cited by Smith, (11), found that pigs farrowed in litters of 7 were most likely to survive.

\section{CORRELATION BETWEEN FACTORS}

The interrelationship between some of the factors influencing the preweaning mortality was studied using the data obtained from 68 purebred Duroc litters and 82 purebred Native litters on which complete information was available.

The factors considered were age, litter number, size of litter, and farrowing weight. The relative importance of the different factors in respect to mortality by means of the multiple regression coefficients is shown in the following tabulation:

\section{Factors}

Age and litter number

Age and litter number and litter size

Age and litter number and litter size and farrowing weight

\begin{tabular}{cc}
\multicolumn{2}{c}{ Coefficients } \\
Duroc litters & Native litters \\
0.0721 & 0.0204 \\
.2650 & .1587 \\
$.4809^{* *}$ & $.4793^{* *}$
\end{tabular}

In both the Natives and the Durocs the regression of the four factors was statistically significant, but the significance was mainly caused by the effect of the farrowing weight. The size of the litter was of some importance but it was not significant. The age and the litter number were of minor importance in the regression.

The following tabulation gives the correlations between the different factors studied and their correlation with the mortality:

\section{Factors}

Age with mortality

Litter number with mortality

Size of litter with mortality

Farrowing weight with mortality

Age with litter number

Age with litter size

Age with farrowing weight

Litter number with litter size

\section{Correlations}

Duroc litters

$-0.0171$

$-.0669$

.2067

$-.4286^{* *}$

$.8741^{* *}$

.1871

.00004
Native litlers

0.0096

$-.0093$

.1573

$-.4729^{* *}$

$.5730^{* * *}$

.1564

.0315 
Litter number with farrowing weight

Litter size with farrowing weight
$-.1016$

$-.2492^{*}$
.1091

$-.1670$

Age and litter number are highly correlated. Naturally, the number of litters farrowed by a sow increases with her age. The litter number has a significant effect on the litter size as shown by the correlation between these two factors in the Duroc litters. The regression of litter size on litter number is given in figure 2. The litter size in the Durocs increased with the litter number up to and including the sixth litter. After the sixth litter the litter size decreased with the litter number.

Anderson (1), stated that best prolificacy was obtained in the sixth or seventh litter. Smith (11), reported data from 10 college and experiment station herds showing a curve similar to that reported here, but concluded that a sow may be expected to produce an increasing number of pigs up to and including her fourth litter, and that from the fourth litter on, she may be expected to produce a decreasing number with each succeeding litter. The regression line for the Native litters confirms this statement.

The litter size has a significant effect on the farrowing weight of the pigs as is shown by the correlation found in the Duroc litters. The regression of farrowing weight on the litter size in this work is shown in figure 3 . The average farrowing weight of the litters decreased as the litter size increased.

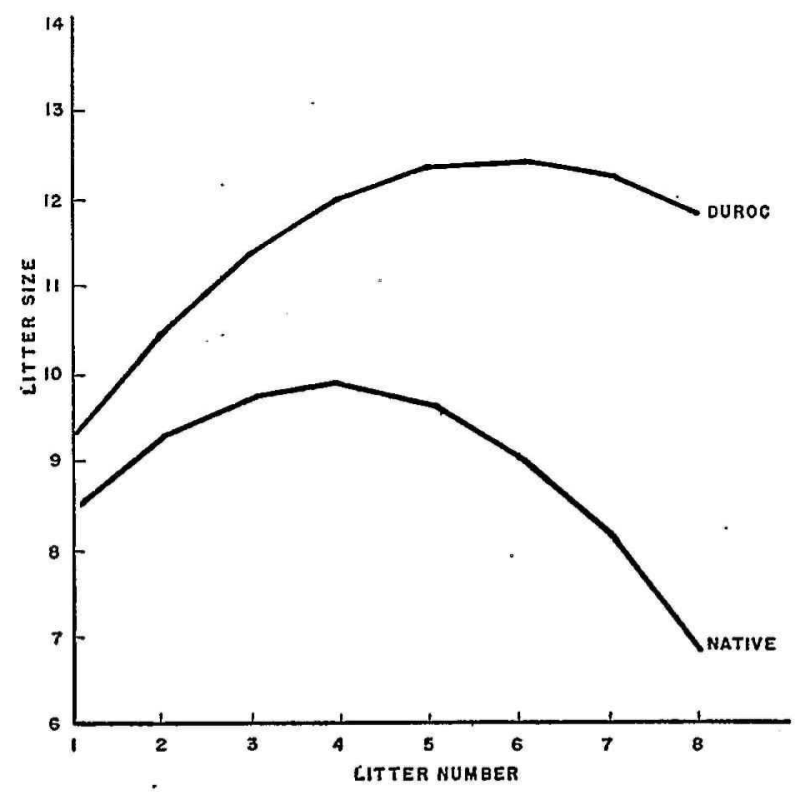

FIG. 2.-Regression of litter number for Native and Duroc pigs. 
Carmichael and Rice (5), reported that as the number of pigs in the litter increased, the size of the individuals quite regularly decreased. GonzálezChapel and Cabrera (7) with a similar group of pigs in Puerto Rico, reported a significant correlation of -0.1790 between litter size and farrowing weight.

Thus, age and litter number have an effect on the litter size. The litter size influences the farrowing weight and the farrowing weight is very important in connection with the mortality. All four factors, therefore, have to be considered when developing a program for reducing the preweaning mortality.

This interrelationship of the factors studied also illustrates the reasons for the important relations found between each individual factor and the mortality. In the age groups, sows of 16 to 23 months, both of the Duroc and the Native breeds, farrowed fewer pigs than sows from 24 to 48 months old, and mortality was consequently reduced. As to the position of the litter, the second litters were smaller than the third to the sixth litters and consequently had lower mortality. The farrowing weight was probably the main cause of the heavier mortality of litters of 12 or more pigs.

\section{CONCLUSIONS AND RECOMMENDATIONS}

The average preweaning mortality of all litters considered in this study was approximately 35 percent of the total pigs farrowed. If due considera-

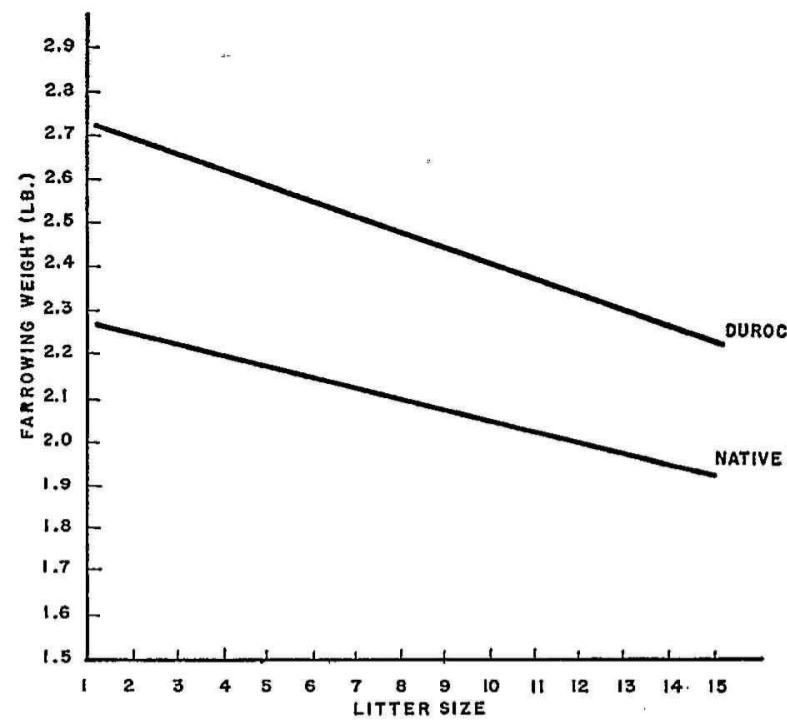

FIG. 3.-Regression of the farrowing weight on the litter size for Native and Duroc pigs. 
tion is given to the fact that the herd studied was probably above average in the Island in respect to management, the conclusion is inescapable that the loss from preweaning mortality is somewhat higher in Puerto Rico than in the States, and that it represents a considerable decrease in the efficiency and economy of swine production in the Island.

Around 70 percent of the mortality in this herd was accounted for by pigs born dead or weak. This shows the need of adequate nutrition of the sow during the gestation period. The use of balanced rations, or of rations containing sufficient of the necessary nutrients, is essential during that period. Special care and attention should be given to the litter during the first 2 weeks after farrowing because most of the losses occur within that period.

Losses of pigs killed by the sows can be reduced sharply by the use of guard rails in the farrowing pen.

Scours, which is an important cause of preweaning mortality, can be prevented by keeping the pigs in dry, warm quarters and by the appropriate feeding of the sow.

Although anemia as a cause of death was of minor importance in this study, it is probably of more importance in the Island as a whole. Hamilton, et al. (8), reported that brushing the udders of the sows with a dilute aqueous solution containing iron, copper, and sirup, or iron and sirup, or iron alone, one or more times daily from farrowing until weaning time, completely prevented anemia in suckling pigs. This udder treatment for the first 4 weeks, followed by allowing the little pigs access to a palatable feed mixture containing 0.1 percent of added ferric sulfate, is an alternative method which seems to be just as efficient as is the udder treatment for the entire 8 weeks.

It has been shown that crossbred litters are generally more vigorous and have lower mortality than purebred litters. In Puerto Rico, where the present need is rather for quantity than for quality of production, crossbreeding could be used to promote swine production. Some reduction in the mortality is also to be expected from use of this system of breeding.

Four-year-old sows, or older sows, should not be kept in the herd unless of good value as breeders. In general, sows should not be kept after their fifth litter is obtained.

The great importance of farrowing weight in relation to subsequent mortality only emphasizes the need for the proper nutrition of the sow during the gestation period.

Pigs in litters of eight or more apparently have more chance of dying than those in litters of eight or less. It is possible that artificial feeding may be the best means of reducing the preweaning mortality. It could be used on the excess pigs in a litter or on the whole litter, as the sole method of feeding 
the pigs, or only as a supplemental method. A complete study of this procedure should be made.

A combination of the proper breeding, care, and management of the herd is thus essential for the reduction of heavy losses occurring during the preweaning period. Careful attention to these phases of swine raising can considerably improve the efficiency and economy of production.

\section{SUMMARY}

The preweaning mortality of 382 litters, comprising 3,841 pigs from different purebred and crossbred sows, was studied.

The average mortality was 35.7 percent. Around 70 percent of the deaths were attributable to still-born pigs or to weak ones that died within the first week after farrowing. Congenital weakness was outstanding among the causes of death.

Some factors influencing preweaning mortality were considered. Summerborn pigs had lower mortality than pigs born in other seasons of the year. Crossbred pigs had lower mortality than purebred. Litters from sows 16 to 23 months old had lower mortality than litters from older sows. Second litters were similarly more vigorous than succeeding litters. Farrowing weight was found to exert an important influence on preweaning mortality; fewer of the heavier pigs died. Litters of 12 or more pigs had higher mortality than smaller litters.

The interrelationship of age, litter number, farrowing weight, and litter size was studied statistically. Age and litter number influenced preweaning mortality mainly through their effect on the litter size, and the litter size through its relation to farrowing weight. Farrowing weight exerted relatively the most important direct effect on mortality.

Some recommendations are made for the reduction of the preweaning: mortality:

(1) Using balanced rations during the gestation period of sows; (2) giving special care and attention to the litter during the first 2 weeks after farrowing; (3) using guard rails in the farrowing pen; (4) keeping pigs in dry, warm quarters; (5) reducing anemia by udder treatment with solution containing iron; (6) producing crossbred litters, if possible; (7) culling sows after their fifth litter or after their fourth year of age.

\section{RESUMEN}

Eiste trabajo incluye un estudio sobre el por ciento de mortandad, antes del destete, de 382 lechigadas. Estas sumaron 3,841 cerditos, hijos de diferentes cerdas cruzadas y de pura raza.

El por ciento de mortandad promedio fué 35.7. Cerca del 70 por ciento de los casos de muerte comprendió los animales nati-muertos y los que 
nacieron muy débiles y que murieron durante la primera semana. La debilidad congénita fué una de las causas más destacadas de la muerte de los cerditos.

Se consideraron algunos factores que influyeron sobre el por ciento de mortandad antes del destete. Los cerditos nacidos durante el verano tuvieron una mortandad más baja que los nacidos en otras estaciones del año; los cruzados también tuvieron una mortandad más baja que los de pura raza. La mortandad en las lechigadas de cerdas de 16 a 23 meses de edad fué más baja que las de las de cerdas de mayor edad. Las segundas lechigadas fueron más vigorosas que las de los partos sucesivos. El peso de los cerditos al tiempo de su nacimiento influyó grandemente sobre la mortandad antes del destete; murió un menor número de los cerditos de mayor peso. Las lechigadas de 126 más cerditos tuvieron un mayor por ciento de mortandad que las de menor número de cerditos.

Se estudió estadísticamente la relación entre la edad, el número de cerditos en la lechigada, el peso al nacer y el número de lechigadas. La edad y el número de lechigadas influyó sobre el por ciento de mortandad antes del destete principalmente, a través de su efecto sobre el tamaño de la lechigada, y éste a la vez a través de la relación con el peso al nacer. Relativamente, el peso al nacer fué el factor más importante, influyendo así más directamente sobre el por ciento de mortandad.

A continuación se hacen algunas recomendaciones para reducir la mortandad antes del destete:

(1) Usense raciones balanceadas durante el período de gestación de las cerdas. (2) Provéanse atención y cuidado especial a las lechigadas durante las dos primeras semanas. (3) Usense cercas protectoras en donde se alojen los cerditos. (4) Los corrales donde se alojen los cerditos deben estar secos y relativamente calientes. (5) Redúzcase la anemia por medio del tratamiento de la ubre de la cerda con una solución que contenga hierro. (6) Si es posible, las lechigadas deben ser cruzadas. (7) Elimínense las cerdas paridoras después que tengan 4 años o 5 pariciones.

\section{LITERATURE CITED}

1. Anderson, A. L., Swine Management, J. B. Lippincott Co., New York, N. Y., 1950.

2. Aubel, C. E., Hughes, J. S., and Lienhardt, H. F., A study of mortality among young pigs, The influence of wheat-germ meal on the reproduction and suckling of pigs, Bull. 31, Kansas Agric. Exp. Sta., 1932.

3. Bagué, J., Cría y cuido de cerdos de pura raza en Puerto Rico, Dept. de Agric. y Comercio de Puerto Rico, 1941.

4. Capó, B. G., A method for the solution of normal equations, J. Agr. Univ. P. R. 28 (1) 1-6 1944.

5. Carmichael and Rice, Ill. Expt. Sta., Bull. 226, 1920. 


\section{JOURNAL OF AGRICULTURE OF UNIVERSITY OF PUERTO RICO}

6. Dale, C. N., Enteritis of swine, U. S. Dept. of Agr. Yearbook, Keeping Livestock Healthy, p. 701, 1942.

7. González-Chapel, A. and J. I. Cabrera, Crossbreeding for swine production in Puerto Rico, J. Agr. Univ. P. R. 33 (4) 1949.

8. Hamilton, T. S., Hunt, G. E., and Carrol, W. E., The prevention of anemia in suckling pigs, with observations on the blood picture, J. Agr. Res. 47 (8) 543631933.

9. Madsen, L. L., Nutritional diseases of swine, U. S. Dept. of Agr. Yearbook, Keeping livestock healthy, p. 816, 1942.

10. MeDonald, G. A., Swine production, Extension Circular 378, South Dakota State College Ext. Serv., 1938.

11. Smith, W. W., Pork production, Armed Forces ed., Macmillian Co., New York, N. Y., 1944.

12. Snedecor, G. W., Statistical Methods, 4th. ed., Iowa State College Press, Ames, Iowa, 1946.

13. Weaver, L. A., Saving the pig crop, Circular 250, Mo. Agric. Expt. Sta., 1943. 